\title{
PERAN BRAND IMAGE MEMEDIASI PENGARUH WORD OF MOUTH TERHADAP PURCHASE INTENTION (Studi Pada Produk Mie Samyang Hot Spicy Chicken di Kota Denpasar)
}

\author{
Ayu Indra Dewi ${ }^{1}$ \\ I Gusti Agung Ketut Sri Ardani² \\ ${ }^{1,2}$ Fakultas Ekonomi dan Bisnis Universitas Udayana (Unud), Bali, Indonesia \\ e-mail : ayuindradewi48@gmail.com
}

\begin{abstract}
ABSTRAK
Penelitian ini bertujuan untuk mengetahui peran brand image dalam mempengaruhi word of mouth terhadap purchase intention. Penelitian ini dilakukan di Kota Denpasar dengan mengambil sample sebanyak 110 responden. Kriteria responden diukur dengan menggunakan teknik purposive sampling. Responden yang dilibatkan memiliki kriteria belum pernah membeli produk mie Samyang Hot Spicy Chicken. Pengumpulan data dilakukan dengan menyebarkan kuesioner yang berisi butir-butir pertanyaan serta diuji dengan menggunakan uji validitas dan uji reliabilitas. Teknik analisis data yang digunakan dalam penelitian ini adalah menggunakan teknik analisis jalur (path analysis) dan teori Solimun. Hasil yang didapatkan dari penelitian ini adalah brand image sebagai variabel yang menjembatani antara pengaruh variabel word of mouth terhadap purchase intention disebut sebagai variabel mediasi sebagian (partial mediation). Hasil ini membuktikan bahwa brand image mampu menjadi variabel mediasi pengaruh word of mouth terhadap purchase intention.
\end{abstract}

Kata kunci : citra merek, niat beli, word of mouth

\begin{abstract}
The purpose of this study is to determine the role of brand image in the influence of word of mouth on purchase intention. This research is conducted in Denpasar City with a total sample of 110 respondents. The criteria of respondents are measured using the purposive sampling technique. The criteria of respondents involved is they have never bought Samyang Hot Spicy Chicken noodle product before. The data collection is conducted by distributing questionnaires which is tested using the validity test and reliability test. The data analysis technique used in this research is the path analysis technique and the Solimun theory. The result attained in this research shows that brand image, as a variable which mediates the influence of word of mouth on purchase intention, is therefore a partial mediator variable. This result proves that brand image is capable of being a mediator variable in the influence of word of mouth on purchase intention.
\end{abstract}

Keywords : brand image, purchase intention, word of mouth 


\section{PENDAHULUAN}

Perkembangan pertumbuhan penduduk tidak dapat dipisahkan pada era globalisasi saat ini. Pertumbuhan penduduk yang cepat membuat kebutuhan pangan meningkat. Tahun 2015 Indonesia menduduki peringkat ke-4 dengan jumlah penduduk terbanyak di dunia (wikipedia.org, 2015). Jumlah penduduk yang tinggi menjadikan Indonesia sebagai negara potensial bagi para importer produk makanan untuk masuk ke pasar Indonesia. Hingga akhir triwulan ke-3 tahun 2016 sektor makanan dan minuman berkontribusi paling besar terhadap pertumbuhan industri di Indonesia (kemenperin.go.id, 2016). Produsen pangan dituntut untuk terus berinovasi ditengah pertumbuhan industri pangan yang pesat. Salah satu inovasi yang dapat dilakukan oleh produsen pangan adalah menciptakan produk makanan instant.

Perkembangan sektor industri pangan sejalan dengan perkembangan gaya hidup masyarakat. Produsen harus beradaptasi dengan perkembangan gaya hidup konsumennya agar dapat merumuskan pendekatan pemasaran yang tepat. Media sosial hadir sebagai media yang paling berpengaruh terhadap gaya hidup konsumen (nasional.kompas.com, 2016). Gaya hidup yang berorientasi pada media sosial menyebabkan media sosial menjadi pedoman dalam mencari infomasi mengenai gaya hidup, kebudayaan dan kuliner (kompasiana.com, 2017), sehingga perkembangan media sosial sangat mempengaruhi pola konsumsi konsumen. Tingkat popularitas sebuah produk dapat meningkatkan rasa penasaran konsumen, sehingga hal ini dapat berpengaruh terhadap niat beli. Referensi konsumen terhadap 
sebuah produk sangat berpengaruh terhadap peningkatan penjualan perusahaan (lifestyle.bisnis.com, 2016).

Fenomena ini direspon oleh perusahaan makanan instan asal Korea Selatan untuk masuk ke pasar Indonesia. Samyang Corporation merupakan perusahaan mie instan, dengan produk andalan Samyang Hot Spicy Chicken yang menawarkan mie instan dengan bumbu cita rasa pedas khas Korea Selatan. Produk Samyang Hot Spicy Chicken menjadi sorotan sepanjang tahun 2016 karena ajang Samyang Challenge di media sosial (liputan6.com, 2016). Challenge tersebut berdampak pada meningkatnya daya tarik konsumen untuk membeli produk Samyang Hot Spicy Chicken.

Niat beli (purchase intention) adalah suatu hal yang merefleksikan rencana pembelian sejumlah produk dengan merek tertentu (Aditya \& Wardana, 2017). Niat beli konsumen dapat timbul dari rasa penasaran konsumen melihat Samyang Challenge yang viral di masyarakat. Hasil wawancara terbuka dengan 15 responden, ditemukan bahwa 10 responden mengetahui produk Samyang Hot Spicy Chicken melalui kerabat serta 5 responden mengetahuinya melalui media sosial. Niat beli dapat dipengaruhi oleh faktor sosial berupa kebudayaan, keluarga, status sosial dan kelompok acuan (Tjiptono, 2005).

Pertengahan Juni 2017 beredar berita dalam mie Samyang mengandung fragmen DNA babi (nasional.kompas.com, 2017). Badan Pengawas Obat dan Makanan (BPOM) menyatakan bahwa ada 4 jenis mie asal Korea Selatan positif mengandung fragmen DNA babi (finance.detik.com, 2017). PT. Korinus selaku pengimpor produk mie Samyang memberikan klarifikasi bahwa produk Samyang 
Hot Spicy Chicken dan Samyang Chesee Hot Chicken Ramen sudah memiliki sertifikat halal dari Korea Muslim Federasi dan sertifikat halal sudah diajukan ke Majelis Ulama Indonesia (bernas.id, 2017).

Beredarnya isu kandungan babi dalam mie Samyang berdampak pada penurunan penjualan sebesar 30\% (megapolitan.kompas.com, 2017). Meskipun terjadi penurunan, masih ada konsumen yang tetap percaya terhadap produk Samyang. Hasil pra-survey pada 15 responden, menunjukkan bahwa 10 responden tidak terpengaruh dengan berita negatif tersebut, 3 responden menyatakan tidak ingin membeli mie Samyang Hot Spicy Chicken karena masalah agama dan 2 responden lainnya menyatakan ragu-ragu dalam mengkonsumsi mie Samyang Hot Spicy Chicken.

Masih terdapatnya niat beli pada produk Samyang dapat disebabkan oleh citra merek (brand image) yang telah melekat di benak konsumen. Citra merek merepresentasikan asosiasi - asosiasi yang diaktifkan dalam memori ketika berfikir mengenai merek tertentu, asosiasi tersebut secara sederhana dapat muncul dalam bentuk pemikiran atau citra tertentu yang dikaitkan kepada suatu merek (Shimp, 2014: 40). Citra merek produk yang baik akan mendorong para calon pembeli untuk membeli produk tersebut dari pada membeli produk yang sama dari merek lain (Seno \& Lukas, 2007). Citra merek juga menjadi pertimbangan penting karena dengan terpenuhinya apa yang dibutuhkan dan diinginkan oleh konsumen maka perusahaan dinyatakan telah memenuhi janji yang dibuat merek tersebut pada konsumennya dan dapat memberikan efek yang positif secara signifikan terhadap niat beli konsumen akan merek tersebut (Sahin et al., 2011). 
Selain citra merek yang kuat, fenomena Samyang Challenge di media sosial menyebabkan produk Samyang Hot Spicy Chicken menjadi produk yang populer di kalangan masyarakat. Viralnya challenge tersebut menyebabkan terbentuknya fenomena promosi dari mulut ke mulut (Word Of Mouth). Word of mouth (WOM) adalah komunikasi berupa pembicaraan maupun testimonial yang dilakukan orang yang membicarakan mengenai suatu produk atau jasa (Basalamah, 2010). Konsumen akan menceritakan pengalamannya menggunakan produk atau jasa dari suatu perusahaan tertentu, atau bahkan sampai tahap merekomendasikan produk atau jasa tersebut kepada orang lain (Permadi dkk., 2014). Rekomendasi produk makanan melalui WOM dapat menimbulkan rasa penasaran yang secara tidak langsung akan menimbulkan niat beli.

Penelitian oleh Torlak et al. (2014) menunjukkan bahwa e-WOM berpengaruh positif terhadap citra merek. Penelitian oleh Aberdeen et al. (2016) yang menyatakan citra merek berpengaruh terhadap niat beli. Hasil berbeda ditemukan oleh Herdani \& Sunaryo (2016), dalam penelitian tersebut WOM tidak berpengaruh signifikan terhadap niat beli. Ketidakkonsistenan hasil temuan ini diduga karena terdapat satu faktor yang mempengaruhi niat beli yaitu citra merek sejalan dengan penelitian yang dilakukan oleh Aberdeen et al. (2016) menyatakan bahwa citra merek memiliki pengaruh positif dan signifikan terhadap niat beli. Citra merek diasumsikan dapat memediasi hubungan antara WOM dan niat beli, untuk membuktikan asumsi ini, diperlukan penelitian lebih lanjut dengan melibatkan citra merek sebagai mediasi hubungan WOM terhadap niat beli. 
Berdasarkan latar belakang yang telah diuraikan maka rumusan masalah dalam penelitian ini antara lain bagaimana pengaruh WOM terhadap citra merek mie Samyang Hot Spicy Chicken, bagaimana pengaruh WOM dan citra merek terhadap niat beli mie Samyang Hot Spicy Chicken, dan bagaimana peran citra merek memediasi WOM terhadap niat beli mie Samyang Hot Spicy Chicken. Dari rumusan masalah tersebut, maka tujuan dari penelitian ini adalah untuk menjelaskan pengaruh WOM terhadap citra merek mie Samyang Hot Spicy Chicken, pengaruh WOM dan citra merek terhadap niat beli mie Samyang Hot Spicy Chicken, dan peran citra merek memediasi WOM terhadap niat beli mie Samyang Hot Spicy Chicken.

Penelitian ini memiliki dua manfaat yaitu manfaat teoritis dan manfaat praktis. Manfaat teoritis berupa hasil dari penelitian ini dapat dijadikan reveresi untuk penelitian selajutnya yang berkaitan dengan WOM, citra merek, dan niat beli. Sedangkan manfaat praktis dari penelitian ini adalah hasil studi ini dapat menjadi referensi dalam mengembangkan strategi pemasaran bagi produk Samyang Hot Spicy Chicken.

WOM mengacu pada pertukaran komentar, pemikiran, atau ide-ide di antara dua konsumen atau lebih yang tidak satupun merupakan sumber pemasaran Mowen \& Minor (2002: 180). WOM adalah suatu bentuk informasi yang disediakan oleh para ahli, keluarga, instansi pendidikan ataupun pelanggan potensial dari suatu produk (Ennew et al.,2000). WOM adalah komunikasi personal antara sasaran pembeli dengan tetangga, teman, anggota keluarga dan pergaulannya mengenai sebuah produk (Kotler \& Amstrong, 2012). Dalam hubungan perusahaan antar 
pelanggan, setiap interaksi antara perusahaan satu dengan perusahaan lainnya, pelanggan selalu menjadi masukan bagi citra merek yang akan ditimbulkan perusahaan karena layanan berkomunikasi adalah sebuah komitmen untuk memberikan pengalaman tertentu, sangat penting bagi perusahaan jasa memastikan bahwa setiap orang dalam organisasi memahami pentingnya penyampaian konsisten, dapat diprediksi, kinerja berkualitas tinggi kepada pelanggan (Webster, 2004). Media komunikasi elektronik yaitu E-WOM menjadi sebuah informasi penting bagi konsumen sehingga pemasar percaya bahwa sabuah situs harus menghasilkan konten yang cukup untuk membangun loyalitas terhadap merek. Selain media, jenis kelamin memiliki pengaruh pada kredibilitas WOM, sikap perempuan dalam menanggapi produk tertentu lebih mudah terpengaruh daripada sikap yang ditunjukan laki-laki (Fan, 2012). WOM merupakan suatu aspek penting dalam strategi suatu perusahaan sekaligus merupakan strategi yang menguntungkan bagi tiap perusahaan yang menerapkan (Chung, 2012). Informasi WOM tersebut langsung berasal dari orang lain yang menggambarkan secara pribadi pengalamannya sendiri (Mowen \& Minor,2002: 180).

Terdapat tiga karakteristik penting dari. Menurut karakteristik dan sifatnya WOM terdiri dari dua jenis, yaitu WOM yang bersifat positif dan WOM yang bersifat negatif (Harsasi, 2006). WOM yang bersifat positif memberikan dampak yang membantu perusahaan untuk tumbuh dengan presepsi positif masyarakat terhadap produk yang dikeluarkan perusahaan. Sebaliknya, pengaruh negatif WOM akan muncul ketika konsumen merasa bahwa produk yang dikeluarkan perusahaan tidak sebaik yang mereka lihat atau dengar dari orang-orang terdekatnya. 
Citra merek merupakan asosiasi-asosiasi yang diaktifkan dalam memori ketika berpikir mengenai merek tertentu (Shimp,2014: 40). Citra dapat terbentuk melalui rangsangan yang datang dari luar sebagai suatu pesan yang menyentuh atau yang disebut informasi yang diterima seseorang. Citra merek adalah suatu persepsi rasional dan emosional konsumen atau pelanggan terhadap suatu merek tertentu (Low \& Lamb, 2000). Citra merek mengacu pada skema memori akan sebuah merek, yang berisikan interpretasi konsumen atas atribut, kelebihan, penggunaan, situasi, para pengguna, dan karakteristik pemasar dan karakteristik pembuat dari produk merek tersebut (Setiadi,2003: 180). Citra merek penting untuk keuntungan masa depan perusahaan dan arus kas jangka panjang mereka, keputusan koalisi dan akuisisi, harga saham mereka, keunggulan kompetitif yang berkelanjutan dan keberhasilan mereka di pasar (Yoo \& Donthu, 2001), sekaligus membuat lebih banyak keuntungan bagi perusahaan (Faircloth et al., 2001). Citra merek yang dikelola dengan baik akan menghasilkan konsekuensi yang positif, oleh sebab itu pengembangan citra merek sangat penting dalam keputusan pembelian (Narjono, 2012). Citra merek berperan penting dalam manajemen pemasaran dan perhatian (Dolich dalam Malik et al.,2012). Asosiasi merek merupakan image penggunaan, image pembelian dan konsumsi yang sesungguhnya (Malik et al.,2012).

Faktor-faktor yang dapat membentuk citra merek diantaranya kualitas, dapat dipercaya, kegunaan atau manfaat, pelayanan, resiko, harga dan citra yang dimiliki oleh merek itu sendiri (Fajrianthi, 2005). Citra merek merupakan representasi dari keseluruhan persepsi terhadap merek dan dibentuk dari informasi dan pengalaman masa lalu terhadap merek itu (Evelina dkk., 2012). Terdapat 4 indikator yang dapat 
digunakan dalam mengukur citra merek (Arsita \& Astuti, 2011), diantaranya : Citra positif, suatu merek memilki citra yang positif dikalangan masyarakat luas, Ciri khas yang berbeda, suatu merek memiliki ciri khas yang berbeda dari pesaingnya, Dikenal masyarakat luas, suatu merek telah dikenal masyrakat luas. Indikator lain dalam pengukuran citra merek dikemukakan oleh Shimp (2014: 40), indikator tersebut diantaranya : Strengthness (Kekuatan), Uniqueness (keunikan) dan Favorable

Niat beli adalah tahap kecenderungan responden untuk bertindak sebelum benar-benar melakukan pembelian (Martinez \& Soyong Kim, 2012). Niat beli adalah suatu hal yang berhubungan dengan rencana konsumen dalam membeli suatu produk tertentu untuk memenuhi kebutuhan pada suatu periode tertentu (Durianto \& Liana,2004). Niat beli sering digunakan oleh para pengusaha untuk memprediksi sikap konsumen ke depannya. Variabel dapat yang mempengaruhi niat beli adalah budaya, kelas sosial, pengaruh pribadi, keluarga, situasi, usability, interaktivitas, keamanan finansial, sumber daya konsumen, motivasi, keterlibatan, pengetahuan, sikap, kepribadian, gaya hidup, demografi, kepercayaan, persepsi manfaat, persepsi keamanan, persepsi kemudahan penggunaan (Hsu et al.,2013 dan Cha, 2009). Beberapa indikator yang dapat digunakan dalam mengukut niat beli yaitu niat eksploratif yang berarti konsumen berniat untuk mencari informasi lebih mendalam mengenai hal-hal positif yang terdapat dalam sebuah produk (Ferdinand, 2002: 129). Indikator lain yang dapat digunakan untuk mengukur niat beli adalah ketertarikan terhadap produk, ketertarikan untuk mencoba dan memiliki produk dan berniat untuk membeli produk tersebut (Calvin \& Hatane, 2014). 
Ayu Indra Dewi, Peran Brand Image Memediasi...

Penelitian yang dilakukan oleh Jalilvand (2012), Torlak et al. (2014), Pertiwi \& Tjok (2014), serta Faresha \& Dimas (2017) menemukan bahwa WOM memiliki pengaruh positif dan signifikan terhadap citra merek. Berdasarkan hasil empiris pada penelitian tersebut, hipotesis yang dapat diajukan dalam penelitian ini adalah: Hipotesis 1 : WOM berpengaruh positif dan signifikan terhadap citra merek.

Penelitian oleh Jalilvand (2012), Khan (2015), Aditya \& Wardana (2017), serta Akbar \& Rosita (2017) menyatakan bahwa WOM memiliki hubungan positif dan signifikan terhadap niat beli. Berdasarkan hasil empiris pada penelitian tersebut, hipotesis yang dapat diajukan dalam penelitian ini adalah:

Hipotesis 2 : WOM berpengaruh positif dan signifikan terhadap niat beli.

Penelitian oleh Cretu \& Brodieb (2007), Wang \& Yang (2010), Rahmawan \& Sigit (2016), Aberdeen et al. (2016), serta Akbar \& Rosita (2017) menemukan bahwa citra merek berpengaruh positif terhadap niat beli. Berdasarkan hasil empiris pada penelitian tersebut, hipotesis yang dapat diajukan dalam penelitian ini adalah: Hipotesis 3 : Citra merek berpengaruh positif dan signifikan terhadap niat beli.

Penelitian oleh Jalilvand (2012), Ruhamak \& Rahayu (2016), Pertiwi \& Tjok (2017), serta Iswara \& Jatra (2017) dalam penelitian tersebut ditemukan bahwa citra merek mampu memediasi hubungan antara WOM terhadap niat beli. Berdasarkan hasil empiris pada penelitian tersebut, hipotesis yang dapat diajukan dalam penelitian ini adalah:

Hipotesis 4 : Citra merek mampu memediasi pengaruh WOM terhadap niat beli.

Berdasarkan kajian pustaka dan hasil studi empiris sebelumnya, maka kerangka konseptual disusun sebagai berikut, 


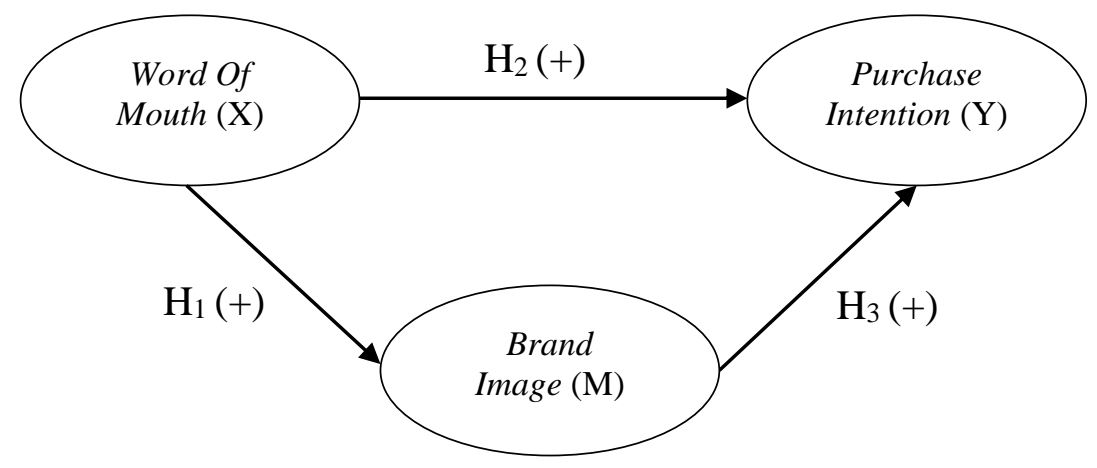

Gambar 1. Kerangka Konseptual

\section{METODE PENELITIAN}

Jenis penelitian dikategorikan sebagai jenis kuantitatif asosiatif karena pada penelitian mebahas hubungan sebab antar variabel berupa WOM, citra merek dan niat beli. Lokasi penelitian dilakukan di Kota Denpasar. Objek penelitian adalah perilaku konsumen khususnya niat beli konsumen yang timbul akibat dari pengaruh citra merek, dan WOM. Pada penelitian ini menggunakan 3 jenis variabel yaitu variabel Indenpenden $(\mathrm{X})$ berupa WOM, variabel mediasi $(\mathrm{M})$ berupa citra merek, dan variabel dependen (Y) berupa niat beli.

WOM merupakan sebuah penyalur pesan informasi yang dilakukan oleh seorang yang bukan pemasar baik melalui media tradisional ataupun modern yang dapat mempengaruhi konsumen lainnya untuk pemasaran produk mie Samyang Hot Spicy Chicken. Citra merek mencerminkan pandangan konsumen kepada merek mie Samyang Hot Spicy Chicken. Niat beli merupakan sebuah rencana konsumen untuk memenuhi sebuah keinginanya kepada produk mie Samyang Hot Spicy Chicken. Indikator dalam mengukur ketiga variabel tersebut disajikan pada Tabel 1. 
Tabel 1.

\section{Pengukuran Variabel Penelitian}

\begin{tabular}{|c|c|c|}
\hline Variabel & Indikator & Sumber \\
\hline WOM & 1) Mendengarkan hal-hal positif & \multirow{3}{*}{ Rosiana (2011) } \\
\hline \multirow[t]{2}{*}{$(\mathrm{X})$} & 2) Memperoleh rekomendasi & \\
\hline & 3) Memperoleh ajakan untuk membeli & \\
\hline Citra & 1) Citra positif & Arsita \& Astuti (2011) \\
\hline Merek & 2) Ciri khas yang berbeda & \\
\hline (M) & $\begin{array}{l}\text { 3) Dikenal masyarakat luas } \\
\text { 4) Favorable }\end{array}$ & Shimp (2014: 40) \\
\hline Niat & 1) Nilai eksploratif & Ferdinand (2002: 129) \\
\hline \multirow[t]{3}{*}{ Beli (Y) } & 2) Ketertarikan terhadap produk & $\&$ \\
\hline & 3) Ketertarikan untuk mencoba dan memiliki produk & Calvin \& Hatane \\
\hline & 4) Berniat untuk membeli & (2014) \\
\hline
\end{tabular}

Populasi yang terlibat adalah masyarakat Kota Denpasar yang tidak pernah membeli produk mie Samyang Hot Spicy Chicken yang tidak diketahui jumlah pastinya. Dalam mentujan jumlah sampel dari populasi tersebut, digunakan teori Sugiyono (2015), dimana jumlah sampel yang terlibat besarnya 10 kali dari jumlah indikator yang digunakan, sehingga jumlah sampel yang terlibat sebesar 110 reponden. Responden yang dapat berpartisipasi dalam pengumpulan data harus memenuhi kriteria tertentu, diantaranya : minimal berusia 17 tahun, jenjang pendidikan minimal SMP, dan belum pernah membeli produk Mie Samyang Hot Spicy Chicken dan berdomisili di Kota Denpasar. Pengumpulan data digunakan dengan menyebarkan kuesioner yang berisi penyataan mengenai variabel WOM, citra merek dan niat beli. Pernyataan dalam kuesioner diukur menggunakan sklaa Likert.

Jenis data yang digunakan dikelompokkan kedalam 2 jenis, yaitu data kuantitatif dan kualitatif, Data kuantitatif berupa usia responden. Data kualitatif berupa pendapat responden terhadap penyataan dalam kuesioner. Sumber data yang digunakan dikelompokkan kedalam 2 jenis, yaitu sumber primer dan sekunder. 
Sumber data primer berasal dari tanggapan responden mengenai kuesioner, sedangkan sumber data sekunder berasal dari publikasi situs berita online.

Instrument berupa kuesioner, terlebih dahulu diuji validitas dan reliabilitasnya. Uji validitas bertujuan untuk mengukur ketepatan kuesioner. Kuesioner dapat dikatakan valid apabila koefisien korelasi $\geq 0,3$. Uji reliabilitas bertujuan untuk mengetahui konsistensi dari kuesioner. Kuesioner dapat dikatakan reliable apabila koefisien alpha cronbach $\geq 0,6$. Hubungan antara variabel WOM, citra merek dan niat beli dapat diketahui melalui analisis jalur (Path Analysis). Selain analisis jalur, Teori Solimun digunakan untuk mengetahui peran citra merek sebagai variabel mediasi. Melalui teori ini akan diketahui citra merek berperan sebagai pemediasi sempurna atau parsial didalam model.

\section{HASIL DAN PEMBAHASAN}

Samyang Corporation adalah perusahaan makanan yang berasal dari Korea Selatan, yang berdiri pada 15 September 1961. Samyang Corporation adalah perusahaan makanan pertama yang memproduksi mie instan. Samyang mulai dikenal di kalangan masyarakat Indonesia sejak tahun 2015 dengan produknya yaitu mie Samyang. Produk-produk dari perusahaan Samyang corporation yang beredar di Indonesia salah satunya adalah Samyang hot spicy chicken, Samyang hot chicken cheese, Samyang u-don, dan Samyang kimchi. Kepopuleran produk Samyang ini membuat produk ini banyak digemari oleh masyarakat Indonesia. Ciri khas ramen dengan bumbu pedas ala Korea Selatan dan berbeda dengan ramen lainnya menjadi daya tarik tersendiri untuk produk ini. 
Jumlah responden yang terlibat sebesar 110 reponden, adapun karakteristik dikelompokkan berdasarkan variabel demografi berupa usia, jenis kelamin dan pekerjaan. Secara lengkap karakteristik dari responden - responden tersebut disajikan dalam Tabel 2. sebagai berikut.

Table 2.

Karakteristik Responden

\begin{tabular}{cllrr}
\hline No. & Variabel & \multicolumn{1}{c}{ Klasifikasi } & Jumlah & Persentase (\%) \\
\hline 1. & Usia & $17-21$ & 71 & 64,5 \\
& & $22-26$ & 33 & 30,0 \\
& & $27-31$ & 2 & 1,8 \\
& & Diatas 32 & 4 & 3,6 \\
& & \multicolumn{1}{c}{ Jumlah } & $\mathbf{1 1 0}$ & $\mathbf{1 0 0 , 0}$ \\
2. Jenis & Perempuan & 63 & 57,3 \\
& kelamin & Laki - laki & 47 & 42,7 \\
& & Jumlah & $\mathbf{1 1 0}$ & $\mathbf{1 0 0 , 0}$ \\
3. & Pekerjaan & 9 & 8,2 \\
& & Pelajar & 65 & 59,1 \\
& & Mahasiswa & 15 & 13,6 \\
& & PNS & 9 & 10,0 \\
& & Pegawai swasta & 10 & 9,1 \\
& & Wiraswasta & $\mathbf{1 1 0}$ & $\mathbf{1 0 0 , 0}$ \\
\hline
\end{tabular}

Data pada Tabel 2. menunjukkan bahwa sebagian besar responden berusia pada rentang 17-21 tahun, dengan presentase sebesar 64,5\%. Responden yang terlibat diambil sebagian besar dari kalangan mahasiswa yang memiliki rata-rata usia 22 tahun. Lingkungan kampus menjadi sangat strategis karena produk Samyang Hot Spicy Chicken lebih banyak dikenal oleh kalangan muda. Sebesar $57,3 \%$ responden dominan berjenis kelamin perempuan. Kaum hawa lebih ingin mencoba produk Samyang Hot Spicy Chicken karena kepopulerannya di media sosial dan mendapat rekomendasi dari teman-teman di lingkungannya. 
Instumen berupa kuesioner diuji menggunakan uji validitas dan reliabilitas, Uji validitas bertujuan untuk mengetahui ketepatan kuesioner, kuesioner dikatakan valid saat koefisien korelasi $\geq 0,3$. Uji reliabilitas bertujuan untuk mengetahui konsistensi kuesioner sebagai alat ukut. Kuesioner dikatakan reliable jika koefisien alpha cronbach $\geq 0,6$. Hasil dari uji validitas dan reliabilitas disajikan dalam Tabel 3. sebagai berikut.

Tabel 3.

Hasil Uji Validitas dan Reliabilitas

\begin{tabular}{clcc}
\hline Variabel & \multicolumn{1}{c}{ Indikator } & $\begin{array}{c}\text { Koefisien } \\
\text { Validitas }\end{array}$ & $\begin{array}{c}\text { Koefisien } \\
\text { Reliabilitas }\end{array}$ \\
\cline { 2 - 4 } WOM & Mendengarkan hal-hal positif & 0,935 & \\
& Memperoleh rekomendasi & 0,935 & 0,921 \\
\multirow{2}{*}{ Citra } & Memperoleh ajakan untuk membeli & 0,924 & \\
Merek & Citra positif & 0,878 & \\
& Diri khas yang berbeda & 0,832 & \multirow{2}{*}{0,891} \\
\multirow{2}{*}{ Niat beli } & Favorable & 0,899 & \\
& Nilai eksploratif & 0,866 & \\
& Ketertarikan terhadap produk & 0,854 & \\
& Ketertarikan untuk mencoba dan memiliki produk & 0,839 & $0,0,757$ \\
& Berniat untuk membeli & 0,928 & \\
\hline
\end{tabular}

Sumber : Data diolah, 2017

Data dari tabel 2. Diketahui nilai koefisien korelasi semua indikator lebih besar dari 0,3 dan nilai dari alpha cronbach lebih besar dari 0,6. Hasil ini menunjukkan kuesioner yang digunakan merupakan instrument yang layak untuk digunakan dan memiliki konsistensi yang baik.

Deskripsi dari masing - masing variabel dapat diketahui melalui rata - rata skor jawaban dari kuesioner. Rata - rata skor jawaban responden pada kuesioner dikelompokkan kedalam 5 kelas interval dengan formula sebagai berikut (Wirawan, $2002: 35)$

$$
\text { Interval }=\frac{\text { Nilai tertingi }- \text { nilai terendah }}{\text { Jumlah kelas }}
$$




$$
\text { Interval }=\frac{5-1}{5}=0,8
$$

Berdasarkan nilai interval tersebut, maka distribusi jawaban responden memiliki rentang penilaian seperti pada tabel 4.sebagai berikut

Tabel 4. Rentang Penlilaian Jawaban Responden

\begin{tabular}{ccc}
\hline No. & Rentang & Kriteria \\
\hline 1. & $1,00-1,79$ & Sangat Tidak Baik \\
2. & $1,80-2,59$ & Tidak Baik \\
3. & $2,60-3,39$ & Cukup Baik \\
4. & $3,40-4,19$ & Baik \\
5. & $4,20-5,00$ & Sangat Baik \\
\hline \multicolumn{2}{l}{ Sumber : Wirawam, 2002} &
\end{tabular}

Deskripsi dari masing variabel WOM, citra merek dan niat beli dijabarkan dalam Tabel 5. sebagai berikut,

Tabel 5.

Hasil Deskripsi Data

\begin{tabular}{|c|c|c|c|c|c|c|c|}
\hline \multirow{2}{*}{ Variabel } & \multirow{2}{*}{ Indikator } & \multicolumn{5}{|c|}{ Distribusi Jawaban (\%) } & \multirow{2}{*}{$\begin{array}{l}\text { Rata- } \\
\text { Rata }\end{array}$} \\
\hline & & 1 & 2 & 3 & 4 & 5 & \\
\hline \multirow[t]{4}{*}{ WOM } & Mendengarkan hal-hal positif & 0 & 0,9 & 16,4 & 57,3 & 25,5 & 4,07 \\
\hline & Memperoleh rekomendasi & 0 & 2,7 & 15,5 & 60,0 & 21,8 & 4,01 \\
\hline & Memperoleh ajakan untuk membeli & 0 & 1,8 & 16,4 & 59,1 & 22,7 & 4,03 \\
\hline & & & & & & Total & 4,04 \\
\hline Citra & Citra positif & 0 & 0 & 15,5 & 56,4 & 28,2 & 4,13 \\
\hline \multirow[t]{4}{*}{ Merek } & Ciri khas yang berbeda & 0 & 0 & 13,6 & 62,7 & 23,6 & 4,10 \\
\hline & Dikenal masyarakat luas & 0 & 1,8 & 19,1 & 49,1 & 30,0 & 4,07 \\
\hline & Favorable & 0 & 0 & 18,2 & 52,7 & 29,1 & 4,11 \\
\hline & & & & & & Total & 4,10 \\
\hline Niat & Nilai eksploratif & 0 & 2,7 & 22,7 & 43,6 & 30,9 & 4,03 \\
\hline \multirow[t]{4}{*}{ Beli } & Ketertarikan terhadap produk & 0 & 3,6 & 21,8 & 46,4 & 28,2 & 3,99 \\
\hline & Ketertarikan untuk mencoba dan memiliki produk & 0 & 1,8 & 24,5 & 46,4 & 27,3 & 3,99 \\
\hline & Berniat untuk membeli & 0 & 3,6 & 18,2 & 48,2 & 30,0 & 4,05 \\
\hline & & & & & & Total & 4,01 \\
\hline
\end{tabular}

Sumber : Data diolah, 2017

Data pada tabel 5, dapat diketahui bahwa variabel WOM mendapatkan ratarata skor 4,04 dimana skor tersebut masuk dalam kategori baik. Skor tertinggi dimiliki oleh indikator mendengarkan hal-hal positif. Sebesar 57,3\% responden setuju dan $25,5 \%$ responden sangat setuju bahwa responden mendengar hal-hal positif mengenai produk mie Samyang Hot Spicy Chicken. Skor terendah dimiliki 
oleh indikator memperoleh rekomendasi. Sebesar $60 \%$ responden setuju dan $21,8 \%$ sangat setuju bahwa responden memperoleh rekomendasi untuk mencoba mie Samyang Hot Spicy Chicken.

Data pada tabel 5, dapat diketahui bahwa variabel variabel citra merek mendapatkan rata-rata skor 4,10 dimana skor tersebut masuk dalam kategori baik. Skor tertinggi dimiliki oleh indikator citra positif. Sebesar $56,4 \%$ responden setuju dan 28,2\% responden sangat setuju bahwa produk mie Samyang Hot Spicy Chicken memiliki citra yang positif dikalangan masyarakat. Skor terendah dimiliki oleh indikator dikenal masyarakat luas. Sebesar $49,1 \%$ responden setuju dan $30 \%$ sangat setuju bahwa mie Samyang Hot Spicy Chicken dikenal oleh masyarakat.

Data pada tabel 5, dapat diketahui bahwa variabel niat beli mendapatkan skor rata-rata yaitu 4,01 yang menunjukkan berada pada posisi interval yang baik. Indikator berniat untuk membeli mendapat nilai tertinggi sebesar 48,2\% responden menjawab setuju dan $30 \%$ responden menjawab sangat setuju. Indikator ketertarikan terhadap produk serta ketertarikan untuk mencoba dan memiliki produk memiliki hasil yang berimbang dengan responden menjawab 46,4\% setuju tertarik, mencoba dan memiliki produk mie Samyang Hot Spicy Chicken dan 28,2\% sangat setuju tertarik terhadap mie Samyang Hot Spicy Chicken serta hasil yang tidak jauh berbeda ditunjukkan oleh indikator ketertarikan untuk mencoba dan memiliki produk.

Untuk mengetahui hubungan antar variabel, hasil data dari kuesioner selanjutnya dianalisis menggunakan teknik analisis jalur. Hasil dari analisis jalur disajikan dalam Tabel 6. 
Tabel 6.

Hasil Analisis Jalur Persamaan Regesi 1

\begin{tabular}{ccccccc}
\hline \multirow{2}{*}{ Model } & \multicolumn{2}{c}{$\begin{array}{c}\text { Unstandardized } \\
\text { Coefficients }\end{array}$} & $\begin{array}{c}\text { Standardized } \\
\text { Coefficients }\end{array}$ & \multirow{2}{*}{ T } & Sig. \\
\cline { 3 - 5 } & B & Std. Error & Beta & & \\
\hline 1 & (Constant) & 6,134 & 1,019 & & 6,018 & 0,000 \\
& WOM & 0,849 & 0,083 & 0,700 & 10,187 & 0,000 \\
\hline $\mathrm{R}_{1}{ }^{2}: 0,490$ & \multicolumn{2}{l}{ F Statistik : 103,778} & \multicolumn{2}{c}{ Sig F : 0,000} & \\
\hline
\end{tabular}

Sumber : Data diolah, 2017

Dari hasil data pada Tabel 6, maka dapat disusun persamaan regresi 1 sebagai berikut :

$$
\mathrm{M}=0,700 \mathrm{X}+\varepsilon_{1}
$$

Nilai koefesien pengaruh WOM terhadap citra merek $\left(\beta_{1}\right)$ adalah sebesar 0,700 dengan nilai $\rho$ value 0,000 . Nilai $\beta_{1}>0$ dan $\rho$ value $<0,05$ sehingga $\mathbf{H}_{\mathbf{1}}$ diterima dan $\mathrm{H}_{0}$ ditolak. WOM memiliki pengaruh yang positif dan signifikan terhadap citra merek.

Tabel 7.

Hasil Analisis Jalur Persamaan Regresi 2

\begin{tabular}{|c|c|c|c|c|c|c|}
\hline & \multirow{2}{*}{ Model } & \multicolumn{2}{|c|}{$\begin{array}{c}\text { Unstandardized } \\
\text { Coefficients }\end{array}$} & \multirow{2}{*}{$\begin{array}{c}\text { Standardized } \\
\text { Coefficients }\end{array}$} & \multirow[t]{2}{*}{$\mathbf{T}$} & \multirow[t]{2}{*}{ Sig. } \\
\hline & & B & Std. Error & & & \\
\hline \multirow[t]{3}{*}{1} & (Constant) & $-1,284$ & 1,218 & & $-1,055$ & 0,294 \\
\hline & WOM & 0,329 & 0,121 & 0,215 & 2,726 & 0,007 \\
\hline & Brand Image & 0,814 & 0,099 & 0,646 & 8,182 & 0,000 \\
\hline & 659 & \multicolumn{2}{|c|}{ F Statistik : 103,542} & \multicolumn{2}{|c|}{ Sig. F : 0,000} & \\
\hline
\end{tabular}

Dari hasil data pada Tabel 7, maka dapat disusun persamaan regresi 2 sebagai berikut :

$$
\mathrm{Y}=0,215 \mathrm{X}+0,646 \mathrm{M}+\varepsilon_{2}
$$

Nilai dari koefisien pengaruh WOM terhadap niat beli $\left(\beta_{2}\right)$ adalah 0,215 dengan nilai $\rho$ value 0,007 . Nilai $\beta_{2}>0$ dan $\rho$ value $<0,05$ sehingga $\mathbf{H}_{2}$ diterima dan $\mathrm{H}_{0}$ ditolak. WOM memiliki pengaruh yang positif dan signifikan terhadap niat beli. Nilai dari koefisien pegaruh citra merek terhadap niat beli $\left(\beta_{3}\right)$ adalah 0,646 
dengan nilai $\rho$ value 0,000 . Nilai $\beta_{3}>0$ dan $\rho$ value $<0,05$ sehingga $\mathbf{H 3}$ diterima dan $\mathrm{H}_{0}$ ditolak. Citra merek memiliki pengaruh yang positif dan signifikan terhadap niat beli.

\section{Tabel 8.}

Hasil Analisis Jalur Tanpa Melibatkan Variabel Mediasi

\begin{tabular}{lcccccc}
\hline \multirow{2}{*}{ Model } & \multicolumn{2}{c}{$\begin{array}{c}\text { Unstandardized } \\
\text { Coefficients }\end{array}$} & $\begin{array}{c}\text { Standardized } \\
\text { Coefficients }\end{array}$ & t & Sig. \\
\cline { 2 - 5 } & B & Std. Error & Beta & & \\
\hline 1 & (Constant) & 3,709 & 1,337 & & 2,773 & 0,007 \\
& WOM & 1,020 & 0,109 & 0,668 & 9,328 & 0,000 \\
\hline $\mathrm{R}_{1}{ }^{2}: 0,441$ & F Statistik $: 87,013$ & Sig F $: 0,000$ & & \\
\hline Sumber : Data diolah, 2017 & & & &
\end{tabular}

Dilihat dari Tabel 6. nilai $\beta_{2}$ ' adalah sebesar 0,668 dengan $\rho$ value sebesar 0,000. Variabel WOM berpengaruh secara signifikan terhadap niat beli tanpa melalui variabel citra merek sebagai variabel mediasi.

Dari hasil analisis jalur persamaan regresi 1 dan 2 maka, selanjutnya akan dihitung nilai dari masing - masing error dengan rumus sebagai berikut,

$$
\begin{array}{lll}
\varepsilon & =\sqrt{1-\mathrm{R}^{2}} \ldots \ldots \ldots \ldots \ldots \ldots \ldots \ldots \ldots \ldots \ldots \ldots \ldots \ldots \\
\varepsilon_{1} & =\sqrt{1-\mathrm{R}_{1}{ }^{2}}=\sqrt{1-0,490}=0,715 \\
\varepsilon_{2} & =\sqrt{1-\mathrm{R}_{2}{ }^{2}}=\sqrt{1-0,659}=0,582
\end{array}
$$

Melaui persamaan 3, diperoleh nilai dari e1 $=0,715$ dan e2 $=0,582$. Selanjutnya hasil perhitungan koefisien determinasi dengan melibatkan nilai dari e1 dan e2 menggunakan rumus sebagai berikut,

$$
\begin{aligned}
\mathrm{R}^{2} \mathrm{~m} & =1-\left(\mathrm{P} \varepsilon_{1}\right)^{2}\left(\mathrm{P} \varepsilon_{2}\right)^{2} \ldots \ldots \ldots \ldots \ldots \\
& =1-(0,715)^{2}(0,582)^{2}=0,828
\end{aligned}
$$

Melaliui persamaan 4 , diperoleh nilai dari $\mathrm{R}^{2}$ sebesar 0,828 . Sebesar $82,8 \%$ variabel niat beli dipengaruhi oleh variabel WOM dan citra merek serta efek dari citra merek sebagai variabel mediasi hubungan WOM terhadap niat beli, sedangkan 
sisanya sebesar 17,2\% dijelaskan oleh faktor lain yang tidak dimasukkan ke dalam model.

Selanjutnya, hasil koefisien jalur pada masing - masing persamaan regresi 1 dan 2 digambarkan pada Gambar 2. sebagai berikut.

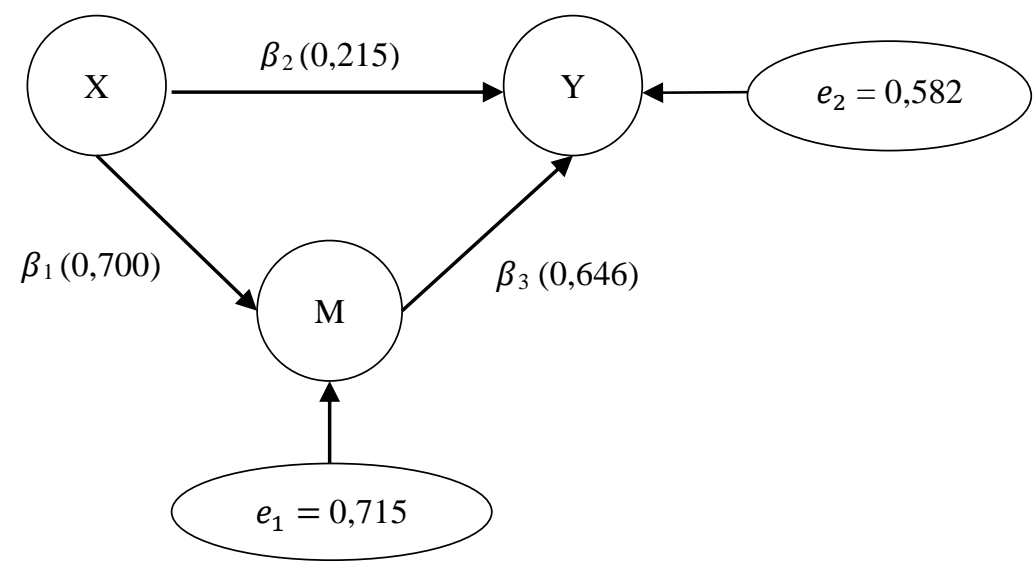

Gambar 2. Validasi Model Diagram Jalur Akhir

Dari diagram jalur pada Gambar 2. maka dapat dihitung besarnya pengaruh langsung, pengaruh tidak langsung serta pengaruh total antar variabel. Perhitungan pengaruh antar variabel ditunjukkan dalam Tabel 7. berikut.

Tabel 9.

Pengaruh Langsung, Pengaruh Tidak Langsung serta Pengaruh Total WOM (X), Citra Merek (M) dan Niat Beli (Y)

\begin{tabular}{cccc}
\hline $\begin{array}{c}\text { Pengaruh } \\
\text { Variabel }\end{array}$ & $\begin{array}{c}\text { Pengaruh } \\
\text { Langsung }\end{array}$ & $\begin{array}{c}\text { Pengaruh Tidak langsung Melalui } \\
\text { Citra Merek } \\
(\mathbf{M})=\left(\boldsymbol{\beta}_{\mathbf{1}} \times \boldsymbol{\beta}_{3}\right)\end{array}$ & $\begin{array}{c}\text { Pengaruh } \\
\text { Total }\end{array}$ \\
\hline $\mathrm{X} \rightarrow \mathrm{M}$ & 0,700 & - & 0,700 \\
$\mathrm{X} \rightarrow \mathrm{Y}$ & 0,215 & 0,452 & 0,667 \\
$\mathrm{M} \rightarrow \mathrm{Y}$ & 0,646 & - & 0,646 \\
\hline
\end{tabular}

Sumber : Data diolah, 2017

Menurut Teori Solimun serta hasil yang didapatkan dari model tanpa melibatkan variabel mediasi dan gambar 2. memenuhi kriteria berupa, hasil analisis koefesien jalur $\beta_{2}$ ' dengan signifikansi sebesar $0,000<0,05$ dan beta sebesar 0,668 maka, WOM berpengaruh signifikan terhadap niat beli. Hasil dari $\beta_{1}$ dan $\beta_{3}$ 
berpengaruh signifikan dengan hasil tingkat signifikansi $\beta_{1}$ sebesar 0,000 dan beta sebesar 0,700 serta hasil tingkat signifikansi $\beta_{3}$ sebesar 0,000 dan beta sebesar 0,646 . Tingkat signifikansi $\beta_{2}$ berpengaruh signifikan sebesar 0,000 dengan beta sebesar 0,215. Hasil koefesien jalur $\beta_{2}$ adalah 0,215 lebih kecil (turun) dari $\beta_{2}$ ' yaitu sebesar 0,668 maka variabel citra merek adalah sebagai variabel mediasi sebagian (partial mediation). Variabel citra merek mampu memediasi WOM terhadap niat beli, sehingga $\mathbf{H}_{4}$ diterima dan $\mathrm{H}_{0}$ ditolak.

Hasil pengujian hipotesis 1 berupa hubungan variabel WOM dan citra merek menunjukkan hasil yang diterima, yaitu WOM berpengaruh positif dan signifikan terhadap citra merek. Semakin baik WOM, maka akan semakin tinggi citra merek. Hasil rangkuman penilai responden yang disajikan dalam deskripsi variabel penelitian menunjukkan bahwa penilaian responden terhadap WOM berada dalam kategori baik sehingga tingkat mendengarkan hal-hal positif mendapat hasil baik. Responden merasa puas ketika mendengarkan hal-hal positif dari produk mie Samyang Hot Spicy Chicken karena adanya citra positif yang tertanam dibenak konsumen, sesuai dengan hasil pada deskripsi variabel penelitian citra positif mie Samyang Hot Spicy Chicken yang mendapat penilaian baik dari responden. Hasil tersebut memperkuat hasil yang ditemukan oleh Reza Jalilvand (2012), Torlak et al. (2014), Pertiwi \& Tjok (2014), dan Faresha \& Dimas (2017) yang menyebutkan bahwa WOM memiliki pengaruh yang positif dan signifikan terhadap citra merek.

Hasil pengujian hipotesis 2 berupa hubungan variabel WOM dan niat beli menunjukkan hasil yang diterima, yaitu WOM berpengaruh positif dan signifikan terhadap niat beli. Semakin baik WOM, maka akan semakin tinggi niat beli 
masyarakat. Hasil rangkuman penilai responden yang disajikan dalam deskripsi variabel penelitian menunjukkan bahwa penilaian responden terhadap WOM berada dalam kategori baik sehingga tingkat mendengarkan hal-hal positif mendapat hasil baik. Responden merasa puas ketika mendengarkan hal-hal positif dari produk mie Samyang Hot Spicy Chicken sehingga konsumen berniat untuk membeli, hal ini didukung dengan hasil pada penyajian deskripsi variabel penelitian. Hasil tersebut memperkuat penelitian yang dilakukan oleh Jalilvand (2012), Khan (2015), Aditya \& Wardana (2017), dan Akbar \& Rosita (2017) yang menyatakan bahwa WOM memiliki hasil yang positif dan sigifikan terhadap niat beli.

Hasil pengujian hipotesis 3 berupa hubungan variabel citra merek dan niat beli menunjukkan hasil yang diterima, yaitu citra merek berpengaruh positif dan signifikan terhadap niat beli. Semakin baik citra merek, maka akan semakin tinggi niat beli masyarakat. Hasil rangkuman penilai responden yang disajikan dalam deskripsi variabel penelitian menunjukkan bahwa penilaian responden terhadap citra merek berada dalam kategori baik sehingga tingkat citra positif mendapat penilaian baik. Responden merasa puas dengan citra positif yang ada pada produk mie Samyang Hot Spicy Chicken sehingga konsumen berniat untuk membeli, hal ini didukung dengan hasil pada penyajian deskripsi variabel penelitian niat beli yang memperoleh penilaian baik. Hasil tersebut mendukung hasil dari penelitian yang dilakukan oleh Wang \& Yang (2010), Rahmawan \& Sigit (2016), Aberdeen et al. (2016) dan Akbar \& Rosita (2017) yang menyatakan citra merek berpengaruh secara positif dan signifikan terhadap niat beli. 
Hasil pengujian hipotesis 4 berupa peran mediasi citra merek pada hubungan WOM terhadap niat beli menujukkan hasil yang diterima. Variabel citra merek dapat memediasi hubungan WOM terhadap niat beli secara parsial. Hasil sebelum adanya variabel citra merek sebagai mediasi yaitu 0,215 namun dengan adanya variabel citra merek sebagai variabel mediasi membuat pengaruh total dari penelitian ini semakin meningkat yaitu mencapai 0,646. Hasil tersebut menunjukkan bahwa citra merek memediasi pengaruh WOM terhadap niat beli secara parsial. Hasil ini juga didukung dengan adanya teori Solimun yang membuktikan bahwa koefesien jalur $\beta_{2}$ sebesar 0,215 lebih kecil (turun) dari $\beta_{2}$ ' yaitu sebesar 0,668 maka variabel citra merek adalah sebagai variabel mediasi sebagian (partial mediation). Hasil penelitian ini mendukung penelitian yang dilakukan oleh Reza Jalilvand (2012), Ruhamak \& Rahayu (2016), Pertiwi \& Tjok (2017), serta Iswara \& Jatra (2017) yang menyatakan citra merek adalah mampu memediasi pengaruh antara WOM terhadap niat beli.

Implikasi dari penelitian ini adalah menekankan manfaat nyata dalam menimbulkan niat beli bagi calon konsumen dan bagi pihak-pihak yang berkepentingan dalam mengembangkan usaha atau jasanya yang sedang dijalankan. Adapun impilikasi penelitian yang dapat ditarik kesimpulannya yaitu yang pertama, perusahaan harus lebih menggencarkan WOM positif yang disebar melalui masyarakat ini terbukti dengan indikator WOM "mendengarkan hal-hal positif" meraih skor tertinggi dari indikator lainnya. Produsen harus tetap memperhatikan isu-isu yang berkembang di kalangan masyarakat agar mampu menimbulkan ketertarikan para konsumen dalam membeli produk. 
Implikasi penelitian yang dapat diambil selanjutnya adalah citra merek sangat berperan penting dalam penelitian ini. Dibuktikan bahwa melalui penyebaran kuesioner yang dilakukan dengan 110 responden indikator "citra yang positif" mendapatkan skor tertinggi dari indikator lainnya, sehingga dapat ditarik kesimpulan bahwa citra merek yang positif akan mampu menambah keinginan konsumen dalam membeli sebuah produk. Hal yang harus digaris bawahi juga terdapat pada indikator "ciri khas yang berbeda" yang menduduki posisi dengan skor tertinggi kedua dari indikator citra merek lainnya. Ciri khas yang berbeda ditunjukkan produk mie Samyang Hot Spicy Chicken dengan berani menampilkan jenis ramen yang berbeda dari pesaing sejenisnya serta berani memasarkan produknya dengan latar belakang rasa bumbu khas Korea Selatan, hal ini menambah sisi positif citra merek yang membuat produk mie Samyang Hot Spicy Chicken menjadi produk yang banyak diminati oleh konsumennya.

Ketiga, indikator berniat untuk membeli mendapatkan skor yang tertinggi yang berarti dengan adanya WOM yang positif dibenak konsumen dan dipengaruhi dengan citra merek yang baik dapat membantu konsumen dengan meyakinkan pilihannya untuk membeli produk Samyang Hot Spicy Chicken. Atas hasil dan temuan yang sudah dipaparkan, maka dapat disarankan bagi pengusaha secara umum dan Samyang Corporation secara khusus untuk tetap menjaga kestabilan fenomena WOM yang menjadi presepsi masyarakat luas agar tidak merusak citra merek yang dibangun untuk memunculkan niat beli para konsumen. Apabila diterapkan dengan dasar yang kuat dan dalam momen yang tepat, strategi ini akan mendatangkan banyak keuntungan positif bagi perusahaan. 


\section{SIMPULAN DAN SARAN}

Berdasarkan pembahasan yang telah dipaparkan diatas, maka dapat ditarik kesimpulan berikut : WOM berpengaruh positif dan signifikan terhadap citra merek, yang berarti citra merek akan sangat berpengaruh apabila timbul WOM yang positif di masyarakat, WOM berpengaruh positif dan signifikan terhadap niat beli, yang berarti semakin positif WOM yang beredar di masyarakat luas akan menimbulkan niat beli konsumen, Citra merek berpengaruh positif dan signifikan terhadap niat beli, yang berarti kekuatan citra merek dapat membantu konsumen untuk menumbuhkan niat beli dan Citra merek berperan dalam memediasi pengaruh WOM terhadap niat beli konsumen, yang berarti semakin baik citra merek yang ditimbulkan oleh perusahaan akan mampu mempengaruhi WOM untuk menimbulkan niat beli pada benak konsumen.

Saran yang dapat diberikan bedasarkan hasil dari penelitian ini adalah ciri khas yang berbeda dapat terus diterapkan di masa yang akan datang mengingat ciri khas yang berbeda sudah menjadi latar belakang dari terciptanya produk-produk Samyang Corporation. Perusahaan harus dapat mempertahankan ciri khas ini untuk menjaga citra merek yang dimiliki oleh perusahaan agar konsumen menumbuhkan niat belinya pada produk-produk yang akan di keluarkan Samyang Corporation di masa yang akan datang. Terbuktinya hasil penelitian secara signifikan yang menggunakan variabel WOM yang dimediasi oleh variabel citra merek untuk meningkatkan niat beli konsumen, hal ini membuktikan penerapan strategi pemasaran WOM yang di padukan dengan citra merek dapat terbilang sukses dan lancar. 


\section{REFERENSI}

Aberdeen, Naufal I., Muhammad S., and Mukhamad N. 2016. The Effect of Brand Awareness and Image on Cusumer Perceived Quality and Purchase Intention - A Study of Carbonated Drink Brand at Bogor City. International Journal of Scientific and Research Publication, 6(8), pp: 441 - 446.

Aditya, Kadek Yoga dan I Made Wardana. 2017. Peran Brand Equity Dalam Memediasi Pengaruh Word Of Mouth Terhadap Purchase intention. E-Jurnal Manajemen Unud, 6 (2), hal.830-856.

Agustinus, Michael. 2017. Industri Makanan dan Minuman RI Makin Tokcer. https://finance.detik.com/industri/3597209/industri-makanan-dan-minumanri-makin-tokcer. Diakses 1 September 2017

Akbar, Ilham dan Nadiyah Hirfiyana Rosita. 2017. Pengaruh Electronic Word of Mouth dan Brand Image Terhadap Minat Pembelian Music Streaming JOOX. Jurnal Ilmiah Mahasiswa Fakultas Ekonomi dan Bisnis Brawijaya, 2 (5), hal.1-17.

Arsita, E.D., dan Astuti, S.R.T. 2011. Analisis Pengaruh Iklan, Kepercayaan Merek, dan Brand image Terhadap Minat Beli Konsumen. Jurnal Ilmu Ekonomi ASET, 13 (1), hal.37-45.

Basalamah, Fauzan M., 2010. Pengaruh Komunitas Merek Terhadap Word of Mouth. Jurnal Ilmu Administrasi dan Organisasi, 17 (1), hal.79-89.

Calvin dan Hatane Semuel. 2014. Analisa Pengaruh Brand Image, Brand Trust dan Economic Benefit Terhadap Niat Pembelian Polis Asuransi PT. SEQUISLIFE di Surabaya. Jurnal Manajemen Pemasaran Petra, 2 (1), hal.111.

Cha, J. 2009. Shopping on Social Networking Web Sites: Attitudes Toward Real Versus Virtual Items. Journal of Interactive Advertising, 10 (1), pp: 77-93.

Chan, Y. Y., and Ngai, E. W. 2011. Conceptualising Electronic Word of Mouth Activity: An Input Process Output Perspective. Marketing Intelligence and Planning, 29 (5), pp: 488-516.

Charo, N., Sharma, P., Shaikh, S., Haseeb, A. and Sufya, M. 2015. Determining the Impact of Ewom on Brand Image and Purchase Intention Through Adoption of Online Opinions. International Journal of Humanities and Management Sciences (IJHMS), 3 (1), pp: 41-46.

Chung, Sheng Lo. 2012. Consumer Decision: The Impact of Word Of Mouth. International Journal of Organizational Innovation, 4 (3), pp: 188. 
Cretu, A. E. and Brodie, R. J. 2007. The Influence of Brand Image and Company Reputation Where Manufacturers Market to Small Firms: A Customer Value Perspective. Industrial Marketing Management, 36 (2), pp: 230 - 240.

Durianto, D. dan C, Liana. 2004. Analisis Efektivitas Iklan Televisi Softener Soft dan Fresh di Jakarta dan Sekitarnya dengan Menggunakan Consumer Decision Model. Jurnal Ekonomi Perusahaan, 11 (1), hal.35-55.

Ennew, C.T., Banerjee, A.K, Li, D. 2000. Managing Word of Mouth Communication: Empirical Evidence From India. International Journal of Bank Marketing, 18 (2), pp: 75-83.

Evelina, Nela., Handoyo D.W., dan Sari Listyorini. 2012. Pengaruh Brand image, Kualitas Produk, Harga, dan Promosi Terhadap Keputusan Pembelian Kartu Perdana Telkom Flexi (Studi Kasus pada Konsumen Telkom Flexi di Kecamatan Kota Kudus Kabupaten Kudus). Jurnal Ilmu Administrasi Bisnis, 1 (1), hal.203-213.

Faircloth, J. B., Louis, M. C. and Bruce, L. A. 2001. The Effect of Brand Attitude and Brand Image on Brand Equity. Journal of Marketing, 9 (3), pp: 61-75.

Fajrianthi., dan Zatul Farah. 2005. Strategi Perluasan Merek dan Loyalitas Konsumen. Jurnal Fakultas Psikologi Universitas Airlangga, 7 (3), hal.276288.

Fan, Y. W., and Miao, Y. F. 2012. Effect of Electronic Word of Mouth on Consumer Purchase Intention: The Perspective of Gender Differences. International Journal of Electronic Business Management, 10 (3), pp: 175.

Faresha, Karlina Siti dan Dimas Hendrawan. 2017. Pengaruh Electronic Word of Mouth Terhadap Purchase Intention yang Dimediasi oleh Variabel Brand Image Pada Situs Travel Online Traveloka (Studi Pada Pengguna di Kota Malang). Jurnal Ilmiah Mahasiswa Fakultas Ekonomi dan Bisnis Brawijaya, 2 (7), hal.1-10

Ferdinand. 2002. Manajemen Pemasaran, edisi ke 1. Jakarta: PT. Penerbit Erlangga.

Ghozali, Imam. 2013. Aplikasi Analisis Multivariate dengan Program IBM SPSS 2.1, edisi ke 7. Semarang: Badan Penerbit UNDIP.

Harsasi, Meirani. 2006. Word Of Mouth dalam Industri Jasa Kaitanya dengan Sikap dan Kemungkinan Membeli. Jurnal Bisnis Strategi, 15 (1), hal.31-41.

Herdani, Rosaristya Ayu dan Sunaryo. 2016. Pengaruh Word Of Mouth, Brand Image, Serta Trust Terhadap Minat Pembelian Produk Prudential Life 
Assurance Di Kota Malang. Jurnal Ilmiah Mahasiswa Fakultas Ekonomi dan Bisnis Brawijaya, 2 (4), hal.1-7.

Herlinda, Wike Dita. 2016. Memetakan Orientasi Industri Kosmetik Global. http://lifestyle.bisnis.com/read/20160220/104/521007/memetakan-orientasiindustri-kosmetik-global. Diakses 26 September 2017

Hsu, C. L., Chuan-Chuan Lin, J., and Chiang, H. S. 2013. The Effects of Blogger Recommendations on Customers online shopping intentions. Internet Research, 23 (1), pp: 69-88.

Ihsanuddin. 2017. MUI Minta Polisi Usut Kasus Mi Samyang Mengandung Babi. http://nasional.kompas.com/read/2017/06/19/12042841/mui.minta.polisi.usu t.kasus.mi.samyang.mengandung.babi. Diakses 20 September 2017

Iswara, I Gede Agus Dana dan I Made Jatra. 2017. Peran Brand Image dalam Memediasi Pengaruh Electronic Word Of Mouth Terhadap Purchase Intention (Studi Kasus Pada Produk Smartphone Samsung di Kota Denpasar). E-Jurnal manajemen Unud, 8 (6), hal.3991-4018.

Khan, S. A., Ramzan, N., Shoaib, M., and Mohyuddin, A. 2015. Impact of Word of Mouth on consumer purchase intention. Journal of Business and Management University of Engineering and Technology, 18 (21), pp: 78.

Kotler, Philip and Armstrong, Gary. 2012. Principles of Marketing, $14^{\text {th }}$ edition. London: Pearson Education.

Kotler, Philip dan Keller, Kevin Lane. 2009. Manajemen Pemasaran, edisi ke 13. Jakarta: Erlangga.

Low, G. S., and Lamb Jr, C. W. 2000. The measurement and dimensionality of brand associations. Journal of Product and Brand Management, 9 (6), pp: 350-370.

Malik, M. E., Naeem, B., and Munawar, M. 2012. Brand Image: Past, Present and Future. Journal of Basic and Applied Scientific Research, 2 (12), pp: 1306913075.

Martinez, B., and Kim, S. 2012. Predicting Purchase Intention for Private Sale Sites. Journal of Fashion Marketing and Management: An International Journal, 16 (3), pp: 342-365.

Mowen, John C dan Michael Minor. (Dwi Kartini, Penerjemah). 2002. Perilaku Konsumen. Edisi 5 jilid 1. Jakarta: PT. Erlangga.

Narjono, Arijo Isnoer. 2012. Atribut Produk sebagai Dasar Pembelian Susu (Studi pada Swalayan Singosari Kabupaten Malang). Ekonomika Jurnal Ekonomi, 5(1), hal.6-11. 
Paramita, Aloysia Nindya. 2017. Pengimpor Mie Samyang Klarifikasi Soal Kandungan Babi. https://www.bernas.id/42883-pengimpor-mie-samyangklarifikasi-soal-kandungan-babi.html. Diakses 21 September 2017

Permadi, Prima C., Srikandi K., dan Andriani K. 2014. Pengaruh Citra Merek Terhadap Word Of Mouth dan Keputusan Pembelian (Survei pada Konsumen Dapoer Mie Galau Jalan Selorejo 83 Malang). Jurnal Administrasi Bisnis (JAB), 10 (1), hal.2-7.

Pertiwi, Komang Yulia dan Tjok Gde Raka Sukawati. 2017. Brand Image Memediasi WOM terhadap Niat Menggunakan Wedding Service di Cahaya Dewi Beauty Salon Denpasar, E-Jurnal Manajemen Universitas Udayana, 6(5), hal.2642-2670.

Prawira, Aditya Eka. 2017. Halal atau Haram Mi yang Digunakan dalam Samyang Challenge. http://health.liputan6.com/read/2996075/halal-atau-haram-miyang-digunakan-dalam-samyang-challenge. Diakses 20 September 2017

Puspita, Sherly. 2017. Penjualan Samyang Halal Merosot 30 Persen. http://megapolitan.kompas.com/read/2017/07/10/15364531/penjualan.samy ang.halal.merosot.30.persen. Diakses 21 September 2017

Rahmawan, Rizky Roezeffian dan Sigit Pramono. 2016. Pengaruh Electronic Word of Mouth Terhadap Niat Pembelian yang Dimediasi oleh Citra Merek Pada Produk Handphone Xiaomi di Malang. Jurnal Ilmiah Fakultas Ekonomi dan Bisnis Brawijaya, 2 (4), hal. 1-18.

Ranny M. 2016. Sektor Makanan dan Minuman Jadi Motor Pertumbuhan Industri. http://agro.kemenperin.go.id/4443-Sektor-Makanan-dan-Minuman-JadiMotor-Pertumbuhan-Industri. Diakses 31 Maret 2017

Reza Jalilvand, M., and Samiei, N. 2012. The Effect of Electronic Word of Mouth on Brand Image and Purchase Intention: An Empirical Study in the Automobile Industry in Iran. Marketing Intelligence and Planning, 30 (4), pp: $460-476$.

Riduwan., dan Kuncoro, Engkos Achmad. 2008. Cara Menggunakan dan Memaknai Analisis Jalur (Path Analysis). Bandung: Alfabeta.

Rosiana, Desak Gede Romilda. 2011. Pengaruh E-Serqual Terhadap Nilai Pelanggan, Kepuasan dan Word of Mouth Communication Anggota Situs Jejaring Sosial Facebook. Tesis. Magister Manajemen Fakultas Ekonomi Universitas Udayana, Denpasar.

Ruhamak, M.D., dan Rahayu, B. 2012. Pengaruh Word of Mouth Terhadap Purchase Intention melalui Brand Image pada Lembaga Kursus Bahasa 
Inggris Dynamic English Course Pare. Jurnal Ekonomi Universitas Kediri, 1 (2), hal.188-204.

Sahin, A., Zehir, C., and Kitapci, H. 2012. The effects of brand experience and service quality on repurchase intention: The role of brand relationship quality. African Journal of Business Management, 6 (45), pp: 11190-11201.

Seno, Diana and Lukas Bryan A. 2007. The Equity of Product endorsement by Celebrities A conceptual Framework from a co branding perspective. European Journal of Marketing, 41(1/2) pp: 121 - 134

Setiadi, Nugroho J. 2003. Perilaku Konsumen Perspektif Kontemporer pada Motif, Tujuan, dan Keinginan Konsumen. Jakarta: PT. Kharisma Putra Utama.

Shimp, Terence A. (Harya Bhima Sena, Fitri Santi, Annisa Puspita Dewi, Penerjemah). 2014. Intergrated Marketing Communication in Advertising and Promotion. Jakarta: Salemba Empat.

Solimun., Adji Achmad Rinaldo Fernandes, dan Nurjannah. 2017. Metode Statistika Multivariat Pemodelan Persamaan Struktural (SEM) Pendekatan WarpPLS. Malang: UB Press.

Sugianto, Danang. 2017. Mie Korea Mengandung Babi Langsung Hilang dari Pasaran. https://finance.detik.com/berita-ekonomi-bisnis/3535499/mie-korea mengandung-babi-langsung-hilang-dari-pasaran. Diakses 21 September 2017

Sugiyono. 2014. Metode Penelitian Bisnis (Pendekatan Kuantitatif, Kualitatif dan $R \& D)$. Bandung: Alfabeta.

2015. Metode Penelitian Tindakan Komprehensif. Bandung: Alfabeta.

Tashandra, Nabilla. 2016. Jutaan Informasi Tersebar di Media Sosial Bagiamana MediaMassaMenjagaAkurasi?.http://nasional.kompas.com/read/2016/03/23/ 21284931/Jutaan.Informasi.Tersebar.di.Media.Sosial.Bagaimana.Media.Ma ssa.Menjaga.Akurasi.?page=all. Diakses 20 September 2017

Tjiptono, Fandy.2005. Pemasaran Jasa. Malang: Banyumedia Publising.

Torlak, O., Ozkara, B., Tiltay, M., Cengiz, H. and Dulger, M. 2014. The Effect of Electronic Word of Mouth on Brand Image and Purchase Intention: An Application Concerning Cell Phone Brands for Youth Consumers in Turkey. Journal of Marketing Development and Competitiveness, 8 (2), pp: 61-68.

Tputri, Nada. 2017. Peran Media Massa Dalam Perubahan Budaya dan Perilaku Masyarakat.http://www.kompasiana.com/nadaayeaah/59bad3b0ed4ed67102 2d7ba2/peran-media-massa-dalam-perubahan-budaya-dan-perilakumasyarakat. Diakses 20 September 2017 
Umar, Husein. 2008. Desain Penelitian Akuntansi Keperilakuan. Jakarta: PT Raja Grafindo Persada.

Wang, X. and Yang, Z. 2010. The Effect of Brand Credibility on Consumers Brand Purchase Intention in Emerging Economies: the Moderating Role of Brand Awareness and Brand Image, Journal of Global Marketing, 23 (3), pp: 177.

Webster, F.E. and Keller, K. L. 2004. A Roadmap for Branding in Industrial Markets. Brand Management, 11 (5), pp: 388-402.

Widyastuti and Erfian. 2012. Quality of Service and Emotion on the Word of Mouth with Customer Satisfaction as the Intervening Variable. Global Network Journal, 5 (2), pp: 338-359.

Wikipedia. 2015. daftar negara menurut jumlah penduduk. https://id.wikipedia.org/wiki/Daftar_negara_menurut_jumlah_penduduk. Diakses 20 September 2017

Wirawan, Nata. 2002. Cara Mudah Memahami Statistik 1 (Statistik Deskripstif) Edisi 1. Denpasar : Keramat Emas

Yoo, B. and Donthu, N. 2001. Developing and Validating a Multidimensional Consumer Based Brand Equity Scale. Journal of Business Research, 52 (1), pp: $1-14$.

Yulius, Jatmiko. 2011. Pengaruh Kualitas Layanan Inti dan Tambahan terhadap Positif Word of Mouth di SMU Semarang. Jurnal Dinamika Manajemen, 13 (1), hal.77-84.

Zhang, R. and Tran, T. 2009. Helping e-commerce Consumers Make Good Purchase Decisions: A User Reviews Based Approach. E-technologies: Innovation in an Open World, LNBIP (26). pp: 1-11. 